logical forces, such as enemies, diseases and meteorological conditions, must be relied upon to check or control this pest.

The feeding of Rhynchites was not confined to the rose flowers or buds, but extended even to clusters of tender, unfolding leaves, which became badly mutilated.

Several pairs of insects were seen mating. Although a special effort was made to observe egg-laying none were seen in the act.

A summary of observations on this insect may be found in Bulletin No. 27 of the Bureau of Entomology by F. H. Chittenden." Specimens have been taken, according to Mr. Chittenden, in various places from the Pacific to the Atlantic, but no outbreak in Massachusetts is recorded. While this year may not be the first appearance of this insect in Massachusetts, it is the first time the damage has been general and noticeable in the central part of the state. Close watch will be kept for its re-occurrence in succeeding years.

\title{
NOTES ON HONEY BEES GATHERING HONEY-DEW FROM A SCALE INSECT, PHYSOKERMES PICEAE, SCHR.
}

\author{
Burton N. Gates, PF. D., Bureau of Entomology, Washington, D. C.
}

It is known that scale insects as well as aphids secrete honey-dew. For instance, Lecanium olea, ${ }^{1}$ upon the citrus fruits of California produce great quantities of honey-dew, which collects as a coating upon the lenves and is a medium for the growth of a fungus, Capnodium sp. The mycilium of this fungus sometimes forms a felt over the leaf, closing the stomata and thus killing the tree.

On the spruces at Amherst, Mass, a scale less well known than this blackscale attracted the writer's attention late in May and in June, 1908. Large numbers of bees were humming in the trees on the campus of the agricultural college. At times the roar was suggestive of a swarm. At first, however, it was thought from the behavior of the bees that they were collecting materials for propolis, but none were seen with a burden packed upon their legs. By following a single bee it was possible to see her on a twig at the union of the last two years' growth searching with extended tongue for something apparently sweet. At the base of what looked to be a bud the bees invariably worked as eagerly as at a drop of honey. This bud-resembling structure was crushed and immediately revealed animal tissue. There were thousands of these bud-like scales on the spruces and from them the bees were busily collecting a liberal store of honey-dew. Some scales, however, apparently produced more of the substance than others, because in some instances globules or dried crystals of honey-dew were noticed at the base of the insects.

Specimens were sent to Mr. J. G. Sanders of the Bureau of Entomology, who determined the scale to be Physokermes picece Schr., "a European species

Washington, 1901 .

1 Kellogg, Vernon L. 1905. American Insects. New York, Henry Holt \& Oo. VIII+674 pp. Page 187. 
which affects the spruce trees and only recently bas been introduced into the United States."

The species is not likely to become a serious pest to the spruces, Mr. Sanders wrote, because of its numerous parasites. Consequently, bee-keeper's will probably not be greatly annoyed with the honey-dew it produces as compared with the large amounts from aphids.

During the past summer (1909) the amount of aphid honey-dew stored by bees has been almost unprecedented in all localities east of the Mississippi, and especially northward. Reports in the apicultural periodicals show excessive production in Illinois, Indiana, Ohio, southern Michigan, Pennsylvania, New Jersey, Maryland and to some extent in New York and New England. In an editorial in Gleanings in Bee Cultures Mr. E. R. Root states: "The abundance of honey-dew [and the resulting admixture with pure honey] will make the year 1909 the shortest on a strictly clear white honey, east of the Mississippi and south of the Great Lakes, that we have ever known." He further adds: "Reports continue to pour in, showing that this is probably the greatest year for honey-dew ever known in this country."

To his knowledge, it has been taken at three points in Massachusetts.

vol. 37, Oct. 1, 1909 , p. 388.

\section{JOURNAL OF ECONOMIC ENTOMOLOGY PUBLISHING COMPANY}

The annual meeting of the stockholders of this company will be held on December 28th or 29th in connection with the Association of Economic Entomologists, at Boston, Mass. The precise time and place will be announced at the sessions of that association. Members of the Advisory Board are hereby notified that it devolves upon them to nominate the elective officers. 